\title{
Humanos, sempre-vivas e outros-que-não- humanos: \\ coletando e compondo o mundo comum no Espinhaço Meridional-MG
}

Humans, sempre-vivas and other-than-humans:

collecting and composing the common world in the Meridional Espinhaço-MG

Bethânia Gabrielle dos Santos e Fátima Teresa Braga Branquinho

\section{(2) OpenEdition}

\section{Journals}

\section{Edição electrónica}

URL: http://journals.openedition.org/aa/6591

DOI: 10.4000/aa.6591

ISSN: 2357-738X

\section{Editora}

Programa de Pós-Graduação em Antropologia Social (UnB)

\section{Edição impressa}

Paginação: 44-63

ISSN: 0102-4302

\section{Refêrencia eletrónica}

Bethânia Gabrielle dos Santos e Fátima Teresa Braga Branquinho, «Humanos, sempre-vivas e outrosque-não-humanos:

coletando e compondo o mundo comum no Espinhaço Meridional-MG», Anuário Antropológico [Online], v.45 n.3 | 2020, posto online no dia 16 setembro 2020, consultado o 27 abril 2021. URL: http:// journals.openedition.org/aa/6591 ; DOI: https://doi.org/10.4000/aa.6591

\section{(c) $($ ) $\odot \odot$}

Anuário Antropológico is licensed under a Creative Commons Atribuição-Uso Não-Comercial-Proibição de realização de Obras Derivadas 4.0 International. 


\section{Humanos, sempre-vivas e outros-que-não-humanos: coletando e compondo o mundo comum no Espinhaço Meridional-MG}

Humans, sempre-vivas and other-than-humans: collecting and composing the common world in the Meridional Espinhaço-MG DOI: https://doi.org/10.4000/aa.6591

Bethânia Gabrielle dos Santos • Universidade do Estado do Rio de Janeiro - Brasil

Doutoranda do Programa de Pós-Graduação em Meio Ambiente da Universidade do Estado do Rio de Janeiro (PPGMA-UERJ). Tem desenvolvido trabalhos no campo da Ecologia Política, com especial interesse nas distintas formas de conhecer e na relação entre humanos e plantas.

Fátima Teresa Braga Branquinho • Universidade do Estado do Rio de Janeiro - Brasil

Professora da Universidade do Estado do Rio de Janeiro. Coordena o grupo de pesquisa Contribuição da Antropologia das Ciências e das Técnicas para a Educação no Programa de Pós-Graduação em Meio Ambiente (PPGMA).

Mundos, humanos, plantas e as conexões que nos agrupam são o fio que guia nossa experiência etnográfica no Espinhaço Meridional-MG. Multiverso onde um grupo de plantas conhecidas como sempre-vivas agencia associações entre humanos e não-humanos. Objeto de investigação científica desde o século XIX, atualmente elas nos fazem produzir políticas ambientais e técnicas de preservação e conservação devido à possibilidade de extinção de espécies. Ao mesmo tempo, comunidades de apanhadores (as) de sempre-vivas contestam a superproteção das mesmas e reivindicam o direito de reprodução de suas práticas como extrativistas. Considerando o cosmos associado a essa controvérsia, estamos compondo um relato ANT sobre a rede sociotécnica das sempre-vivas no Espinhaço. Com ele pretendemos conhecer melhor nossa própria comunidade, o modo como produzimos conhecimento, e as possibilidades de diálogos entre ontologias e coletivos heterogêneos que nos permitam tecer um mundo onde caibam muitos mundos.

Humanos. Plantas. Sempre-vivas. Teoria Ator-Rede. Antropologia da Ciência e da Tecnologia.
Worlds, humans, plants and the connections that put us together are the thread that guides our ethnographic experience in the Espinhaço Meridional-MG. Multiverse in which a group of plants known as sempre-vivas (everlasting flowers) agencies associations between humans and non-humans. Subjects of scientific research since the 19th century, currently they make us develop environmental policies and techniques of preservation and conservation, given the possibility of species extinction. At the same time, flower picker communities contest the overprotection and claim for their rights to develop extractivist practices. Considering the cosmos associated with this controversy, we are composing an ANT account about the sempre-vivas socio-technical networks in the Espinhaço. We intend to gain a better knowledge of our community, our ways of producing knowledge and the possibilities of developing dialogues between heterogeneous ontologies and collectives that enable us to build a world of many worlds.

Humans. Plants. Sempre-vivas (Everlasting flowers). Actor-network Theory. Anthropology of Science and Technology. 


\section{Introdução: plantas como mediadores cósmicos}

Nunca poderemos compreender uma planta

sem ter compreendido o que é o mundo.

(COCCIA, 2018, p. 13)
Marginalizada tanto nas Ciências Naturais - sobretudo na Biologia, estruturada sobre o mundo animal - quanto nas Ciências Humanas - obstinadas em compreendê-la como um fato puramente natural, e, portanto, excluído do seu domínio -, a vida vegetal é geralmente percebida por nós humanos como imóvel, não senciente e passiva, ocupando o limbo entre o vivo e o não vivo.

Nas últimas décadas, um movimento conhecido como a virada das plantas tem contestado essa insuficiência epistemológica, com a produção de conhecimento relativo à consciência e ação no mundo vegetal (Calvo, 2017; Myers, 2014), além de sustentar o debate sobre o que denomina cegueira vegetal ${ }^{1}$ (Wandersee; Schussler, 1999). O termo refere-se à dificuldade humana em perceber as plantas, não apenas sensorialmente, mas estendendo-se à inabilidade de entendermos a trama de nossas relações com estes seres (Calvo, 2017; Halpin; Mckim, 2019; Nichols et al., 2013; Schussler; Olzak, 2008; Sanders, 2019).

Nessa fase da crise ecológica - considerada um evento limite denominado Antropoceno devido às proporções planetárias dos processos antrópicos (Crutzen; Stoermer, 2000), ou Plantatioceno e Capitaloceno, enfatizando o modo de produção responsável pelas mudanças globais (Haraway, 2016; Moore, 2016) - reconhecemos a importância da discussão sobre a cegueira vegetal para entendermos o momento apocalíptico que parecemos viver. Entretanto, dada a intrusão de Gaia ${ }^{2}$ (Stengers, 2009) em nossas vidas, acreditamos que as plantas podem nos falar mais que sobre os eventos catastróficos que nos atormentam.

Em um planeta vivo, elas - que produziram a atmosfera e transformam a energia solar dispersa em corpo vivo - são o elo produtor das cadeias alimentares dos meios aquáticos e terrestres. Elas - que viram o ambiente terrestre antes que fosse habitado por outras formas de vida e o prepararam para que a evolução fosse possível - são o corpo da gênese constante de nosso cosmos, com circulação de seres vivos, e disseminação das formas, diferenças de espécies e modos de vida (Coccia, 2018). Elas - que conectam céu e terra, aderem-se integralmente ao entorno que as acolhe e simplesmente por existirem o modificam - são muito mais que testemunhas silenciosas da história da Terra.

Quando o Antropoceno transforma o que define a existência do mundo em algo único, histórico e negativo, a natureza em uma exceção cultural e os humanos em causa extra-natural, as questões que nos movem dizem respeito ao que a vida destes mediadores cósmicos ontologicamente anfíbios (Coccia, 2018) pode nos revelar sobre nosso mundo.

Caminhando pelo Espinhaço, um conjunto de serras ou cordilheira que se estende de Minas a Bahia, estamos seguindo as sempre-vivas, um grupo de plantas (atores-rede, ou objetos científicos-técnicos) ao qual se prende um curso de ação co-
1 Considerada a devida importância do termo para o florescimento de inúmeros estudos relativos à vida das plantas, Mackenzie et al. (2019) ressaltam como ele pode ser problemático na medida em que recorre aos estereótipos de incapacidade atribuídos às pessoas com deficiência. Ainda ressaltam que, usando essas metáforas, sugerimos que deficiências são condições que exigem "curas" ou "prevenções" (Mackenzie, 2019).

2 Para Isabelle Stengers (2009), dada a atual situação da crise ecológica, cabe a nós criar uma maneira de responder, por nós, mas também pelas inúmeras espécies vivas que levamos conosco para a catástrofe. Portanto, temos que criar uma resposta para o que ela denomina intrusão de Gaia. Aqui Gaia não se refere à Terra concreta, tampouco àquela invocada quando falamos de nossa conexão com a mesma. Remete ao planeta vivo, entendido como ser dotado de história e um regime de atividade próprio. Já não estamos lidando com uma natureza selvagem e ameaçadora, sequer com uma natureza frágil que deve ser protegida, muito menos com uma natureza que pode ser explorada à vontade. Diante da intrusão, ou dos desastres que se anunciam, Gaia não nos pede nada. 
letiva de produção do conhecimento sobre a realidade. As sempre-vivas estão enredadas em formações políticas com múltiplos atores. Neste coletivo ${ }^{3}$ onde todo ator é capaz de provocar transformações, elas são agentes ativos e participam de uma malha aberta de associações - rede - que conecta científico e político, tradicional e moderno, acadêmico e popular, micro e macro, individual e coletivo, humanos e não-humanos em seu lugar (Latour, 1994, 2016; Sanders, 2019; Tsing, 2012).

Neste artigo tratamos desta experiência etnográfica que com a Teoria Ator-Rede (ANT) (Latour, 1994) tem se dado nos entremeios (Marras, 2018), em uma proposição cosmopolítica ${ }^{4}$ (Stengers, 2014). A cosmopolítica designa que não haja política que não considere o cosmos, o público associado a cada assunto de disputa. Esta composição se justifica quando, em um mundo tecido pela mistura, seguimos produzindo conhecimento sobre a realidade a partir dos cortes que separam o conhecimento das coisas, e o poder e a política dos homens (Latour, 1994).

Investigando questões ambientais em comunidades rurais do Espinhaço desde meados de $2015^{5}$, aqui resgatamos informações provenientes de variadas fontes, mas agora com o objetivo específico de seguir o rastro destas plantas. Vendo, ouvindo e aprendendo com interlocutores diversos, analisando anotações de campo, documentos e revisitando memórias, estamos compondo um cosmograma (Latour, 2016). O arranjo das associações de conveniência, coexistência, oposição, e/ou exclusão entre os mundos dos atores que elas agenciam.

Para tanto, foram indispensáveis o levantamento documental realizado a partir do final de 2017 em repositórios digitais e herbários virtuais onde tivemos acesso a revistas, artigos científicos, imagens, planos de conservação e legislação sobre a flora brasileira; os livros raros da Biblioteca Pública Estadual e Arquivo Público Mineiro em Belo Horizonte, das Bibliotecas da Universidade de São Paulo e as exposições da Casa da Gloria em Diamantina, onde obtivemos alguns registros da produção científica dos naturalistas no Brasil; como também material audiovisual (tais como documentários) e proveniente de sites e redes sociais que nos permitiram fertilizar nosso conhecimento sobre povos e comunidades tradicionais locais.

Articuladas ao levantamento documental estiveram nossas incursões ao Espinhaço, sobretudo à sua porção Sul - na região da Serra do Cipó - e meridional - na região das cidades de Diamantina, Serro, e comunidades rurais dos arredores (tais como Milho Verde, Capivari e São Gonçalo do Rio das Pedras). Entretanto, como um trabalho ANT necessariamente busca romper com a hierarquia sujeito-objeto ou pesquisador-pesquisado, revisitando o que Roberto Cardoso de Oliveira (1996) nos ensina sobre olhar, ouvir e escrever, em nosso ofício optamos por não solicitar entrevistas ou distribuir questionários. Como os relatos são o laboratório do cientista social e no interior de Minas o "dedo de prosa" ou o "causo" são elementos de interação que surgem espontaneamente, através da observação e da escuta atenta fomos capazes de conhecer a vida local no convívio do dia a dia, participando de festividades, feiras e assembléias científico-políticas. Tais como o I Festival dos Apanhadores e Apanhadoras de Sempre-Vivas, que aconteceu em Diamantina no ano de 2018 e o $39^{\circ}$ Encontro Regional de Botânica (ERBOT) realizado na Universidade Federal dos Vales do Jequitinhonha e Mucuri em $2019^{6}$.
3 Ao contrário da sociedade, que é um artefato imposto pelo acordo modernista, esse termo se refere às associações de humanos e não-humanos. Se a divisão entre natureza e sociedade torna invisível o processo político pelo qual o cosmos é coletado num todo habitável, a palavra "coletivo" torna esse processo crucial (Latour, 2001, p. 358).

4 Proposição que pressupõe que o conhecimento coletivo se constrói em um espaço de encontro de heterogeneidades, um cosmos. Na medida em que habitamos um pluriverso que requer uma cosmopolítica, o mundo comum é um possível resultado e não um ponto de partida.

5 Nossa inserção em campo no Espinhaço se deu no ano de 2015, com um estudo de caso relativo às interações socioambientais em Milho Verde, distrito da cidade de Serro onde estivemos em contato com moradores, ONGs e Órgãos Ambientais locais. Para mais, ver Santos (2016).

6 O I Festival dos Apanhadores e Apanhadoras de Sempre-Vivas contou com a presença de cientistas sociais e naturais, das comunidades de apanhadores(as) do Espinhaço Meridional, representantes de movimentos sociais, do poder público e da Organização das Nações Unidas para a Alimentação e a Agricultura (FAO, sigla do inglês Food and Agriculture Organization). No evento foi feita a entrega do dossiê da primeira candidatura brasileira ao programa Sistemas Importantes do Patrimônio Agrícola Mundial (SIPAM/FAO). O evento contou ainda com mostra fotográfica, feira com produtos artesanais das comunidades e uma série de apresentações culturais. Já o $39^{\circ}$ ERBOT reuniu botânicos e profissionais das ciências da terra de distintas universidades, institutos de pesquisa e países, todos com interesse em dialogar sobre a flora regional. 
Assim estamos descrevendo esta rede sociotécnica fluida que envolve presente, passado e futuro, pois, como veremos, com as plantas temos aprendido que etnografar se trata menos de definir um universo, mas de coletar e compor um cosmos (Latour, 2016). Isto é o que estamos tratando de fazer em diálogo com as serras de Minas, seus vegetais, águas, pedras, bichos, coisas, gente. Bem como com as ciências e técnicas de arqueólogos, naturalistas, biólogos, agrônomos, ambientalistas, cientistas sociais, gestores públicos, apanhadores(as) de flores, etc. Todos visualizados em um mesmo plano.

\section{Primeiros rastros: humanos e as plantas do Espinhaço}

O Espinhaço é um extenso maciço que recobre a porção oriental da Plataforma Sul-Americana. Estende-se no sentido N-S por mais de $800 \mathrm{~km}$, desde o paralelo $20^{\circ} \mathrm{S}$ nas proximidades da Serra do Cipó em Minas Gerais, até o paralelo $12^{\circ} \mathrm{S}$, já no estado da Bahia (IBGE, 2006).

As denominações utilizadas para a cordilheira consideram a área de ocorrência de seus diferentes segmentos, a saber: (i) Espinhaço Meridional que se estende desde as proximidades de Belo Horizonte e prolonga-se ininterruptamente até a região de Olhos D’Água (Minas Gerais); (ii) Serra do Cabral, segmento ocidental da cadeia em Minas Gerais, incluindo a Serra da Água Fria; (iii) Espinhaço Setentrional que se inicia na altura do paralelo $17^{\circ} 30^{\prime} \mathrm{S}$, em Minas Gerais, onde a serra ocorre separada e deslocada por aproximadamente $30 \mathrm{~km}$ na direção NNE da parte Meridional, com prolongamento contínuo do flanco oriental até o Estado da Bahia; (iv) Chapada Diamantina, distribuindo-se inteiramente na porção centro-oriental da Bahia (Chemale Jr. et al., 2011, p. 173).

Constitui o grande divisor de águas entre as drenagens das bacias do Rio São Francisco, a oeste, e do Rio Doce, Rio Jequitinhonha e outras menores a leste. Em termos fitogeográficos, localiza-se entre os domínios da Mata Atlântica e do Cerrado. O tipo vegetacional predominante é o campo rupestre. A fisionomia de seu relevo, modelado por cisalhamentos e fraturas, apresenta formações de abrigos rochosos nos quais se nota a presença de vestígios que revelam relações pré-históricas ${ }^{7}$ e históricas entre humanos e as plantas do lugar (Horta, 2009; Solari; Isnardis; Linke, 2012).

Ao norte de Belo Horizonte, a região de Lagoa Santa e a encosta da Serra do Cipó apresentam importantes coleções para o estudo biológico das primeiras populações americanas. Muito parecidas entre si, elas formam a chamada "raça de Lagoa Santa" (Prous, 2006). Ali, entre 11.000 e 8.000 anos atrás, grande número de abrigos e salões de entrada de grutas foi utilizado como cemitério por grupos humanos.

Escavações realizadas nestes locais revelaram corpos depositados em pequenas covas, acompanhados de colares e sementes. Pinturas rupestres atribuídas a uma fase tardia da Tradição São Francisco, localizadas ao longo do rio homônimo (PEREIRA, 2013), e depósitos de material vegetal como concentrações de
7 Para arqueólogos e paleontólogos, as rochas são como fotografias que contam a história passada, presente e futura dos humanos e demais seres vivos. Com a Paleobotânica, a história dos grupos vegetais pode ser visualizada e documentada através de estruturas fósseis macroscópicas (folhas, ramos, lenho, sementes, flores, frutos) e microscópicas (grãos-de-pólen, esporos, cutículas) (Souza, 2015). 
palha, coquinhos, fragmentos de espigas de milho e sementes atestam a prática de cultivo de plantas domésticas e criação de reservas alimentares por populações pré-históricas (Horta, 2009). Junto a um desses depósitos foi encontrada também uma flor seca (Horta, 2009, p. 231), uma sempre-viva.

Diante deste indício da ancestralidade da relação entre humanos e esse grupo de plantas, estamos seguindo-as pelas serras de pedras ora feito águias, ora feito formigas míopes (Latour, 2012). Seja do alto ou bem próximo ao chão, as sempre-vivas nos falam de um passado sempre presente na vida dos mineiros, ou de como a história do Espinhaço está entretecida à história do colonialismo no Brasil.

Até meados do século XVI, Minas Gerais era o Sertão 8 dos Cataguases; aos olhos da metrópole, um vazio demográfico com presença de populações ditas "pré-civilizadas". Com a descoberta de ouro no início do século XVII, iniciou-se um processo de escravização e extermínio das populações originárias, e ocupação do sertão mineiro por exploradores, com a construção de vilas e lugarejos coloniais. Tais como o Tejuco, um pequeno arraial que teve notoriedade nessa época por ser locus da descoberta de diamantes e que na atualidade carrega o topônimo Diamantina.

Durante o Brasil Colônia, atividades particulares de mineração ocorreram em diversas porções do Espinhaço. Com a queda da arrecadação de impostos em fins do século XVIII e início do XIX, a Coroa contrata o engenheiro alemão W. L. Eschwege para realizar estudos sobre as riquezas existentes no Distrito Diamantino?.

Eschwege veio para o Brasil em 1810, como diretor do Real Gabinete de Mineralogia do Rio de Janeiro, encarregado de incrementar as técnicas de mineração. De sua estada em Minas Gerais resultaram diversos relatos publicados, sobretudo na Alemanha. Em um desses artigos, pela primeira vez foi nominado como Espinhaço o conjunto de serras que apontava Norte-Sul ou Minas-Bahia (Eschwege, [1822] 2005).

Uma dessas principais cadeias montanhosas, chamada em alguns lugares de Serra da Mantiqueira, encerra os pontos mais altos do Brasil, tais como o Pico do Itacolumi perto de Vila Rica, a Serra do Caraça junto a Catas Altas e o majestoso Pico do Itambé, perto da Vila do Príncipe, e atravessa, pelo norte, as províncias de Minas Gerais e da Bahia seguindo até Pernambuco e para o sul, a de São Paulo até o Rio Grande do Sul. A ela denominei Serra do Espinhaço ("Rückenknochengebirge"), não só porque forma a cordilheira mais alta, mas, além disso, é notável, especialmente para o naturalista, pois forma um importante divisor não somente sob o ponto de vista geognóstico, mas também é de maior importância pelos aspectos da fauna e da flora. [...] As regiões ao leste desta cadeia, até o mar, são cobertas por matas das mais exuberantes. $\mathrm{O}$ lado oeste forma um terreno ondulado e apresenta morros despidos e paisagens abertas, revestidas de capim e de árvores retorcidas, ou os campos cujos vales encerram vegetação espessa apenas esporadicamente. O botânico encontra, nas matas virgens, plantas completamente diferentes daquelas dos campos e o zoólogo acha uma outra fauna, especialmente de aves, tão logo passe das matas, pela Serra do Espinhaço, para os campos (Eschwege, [1822] 2005, p. 99).
8 Palavra utilizada pelos portugueses desde a Idade Média para referir-se a áreas afastadas de Lisboa. Provém do latim sertanum (trançado, entrelaçado, enredado, enfileirado) ou de desertanum (lugar não entrelaçado ao conhecido; lugar para onde foi o desertor, aquele que saiu da linha). Assim, no século XVI passou a ser utilizada nas colônias para designar lugares interiores desconhecidos, habitados pela natureza bruta e povos ditos "incivilizados" (Amado, 1995).

9 Com o fim de aumentar ao máximo o controle da Coroa sobre o diamante extraído, parte do território mineiro passou a compor o Distrito Diamantino. Demarcado inicialmente em 1731, tratava-se de um quadrilátero em torno do Arraial do Tejuco, que foi designado sede tanto do Distrito quanto da Intendência. 
O relato de Eschwege é importante na medida em que borra as demarcações entre campos do saber e entre ciência e política. Isto porque transcende as informações que hoje conteria um relatório mineralógico e evidencia as relações políticas que permitiram o financiamento das primeiras investigações científicas na região. Relações essas que foram determinantes para que uma comitiva de cientistas austríacos e bávaros acompanhasse Leopoldina ao Brasil, quando a princesa se casa com o Imperador Dom Pedro I em 1817.

Dentre estes destacamos o botânico Martius (1794-1868) que com o zoólogo Spix (1781-1826) viajou do Rio de Janeiro ao Amazonas, descrevendo em seus cadernos de campo aspectos que hoje classificaríamos como biológicos, antropológicos, sociológicos, geográficos e geológicos. Através desses registros que tratavam das relações que, supunha-se, regiam a vida cósmica (Kury, 2001), nos deparamos com um Espinhaço que acreditamos ser um mundo entre muitos. Como veremos um multiverso inundado de passado, mas que já não é o mesmo.

\section{Seguindo as sempre-vivas: Nas serras de Minas se faz ciências}

Durante os três anos que esteve no Brasil, a principal incumbência de Martius foi o estudo das plantas tropicais, buscando compreender a expansão do reino vegetal sobre a terra. Como resultado desse empreendimento, foi produzida a Flora Brasiliensis, obra com 40 volumes - onde foram identificadas mais de 22.000 espécies - e que contém as primeiras descrições científicas das sempre-vivas da Cordilheira do Espinhaço (Figura 1).

De certo modo, a vegetação do Distrito Diamantino é a mais peculiar e bem formada flora dos campos que se observa no planalto. As entroncadas Liliáceas arbóreas, Velózias e Barbacênias, são aqui mais abundantes do que nas outras partes de Minas, e são mesmo consideradas, pela gente do lugar, como indício da existência do diamante. Por entre as gramíneas peludas, verde-cinzentas, que, em grandes extensões, revestem as planícies deste Distrito, sobretudo são as Eriocauláceas que estão em grande número, com as suas umbelas de flores alvas pequeninas (Spix; Martius, [1824] 1981, p. 43, grifo nosso).

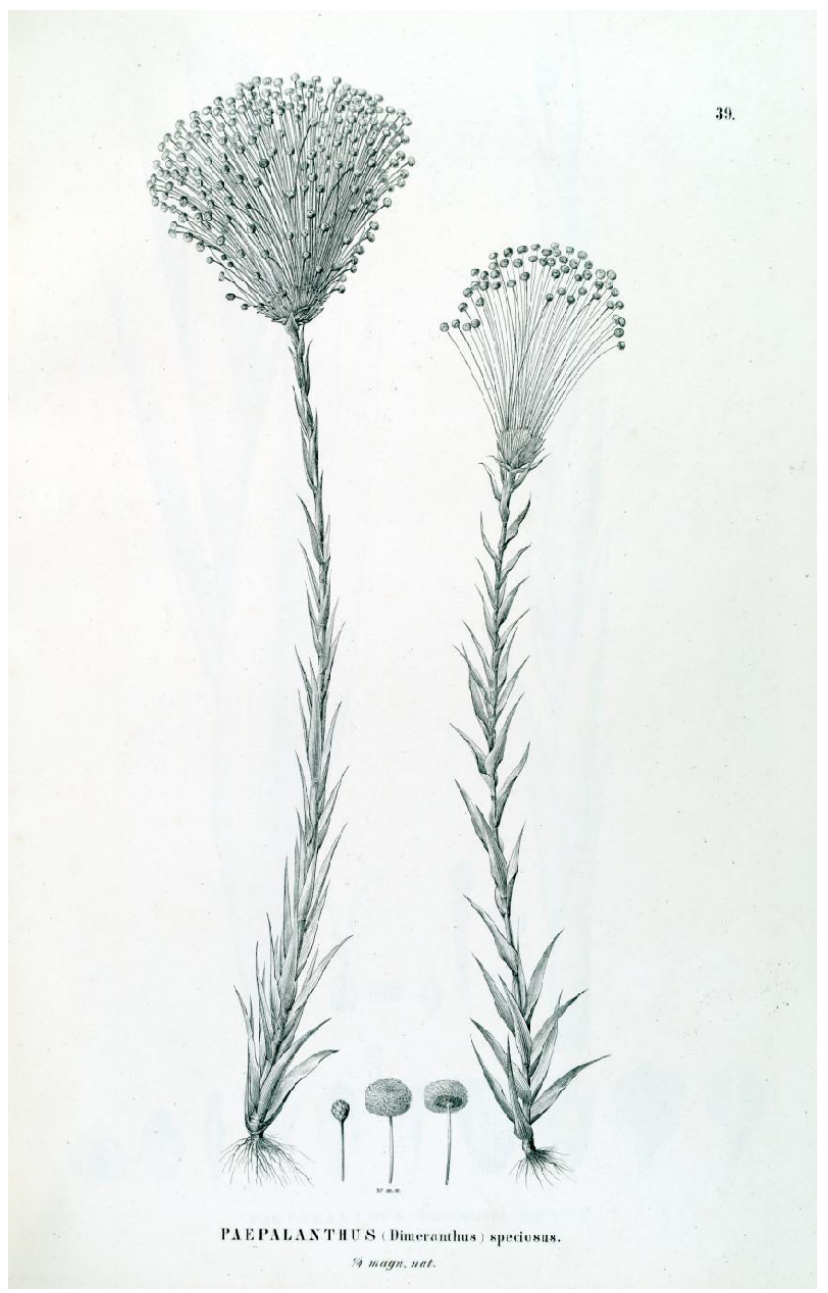

49

Figura 1: Ilustração de Paepalanthus (Dimeranthus) speciosus. Na atualidade Paepalanthus é o maior gênero de Eriocaulaceae, compreendendo cerca de 400 espécies distribuídas principalmente nos neotrópicos. Fonte: Martius; Eichler; Urban (Orgs.), 1906. 
Sobre o trabalho deste naturalista e dos demais que por aqui estiveram, é importante ressaltar como seu material era obtido seguindo uma série de exigências para assegurar sua conservação e identificação. No caso do material botânico, esse deveria ser armazenado em forma de exsicata. Uma exsicata é uma amostra de planta ou alga prensada, seca, fixada em papel, contendo informações sobre o espécime, seu coletor, o identificador do material, data de coleta e local. Olhando um desses exemplares vegetais - que para os botânicos só tem valor em si quando acompanhado da etiqueta que informa os humanos que o coletaram e em qual local específico - ele sugere como fomos alienados de nossas plantas, ou ainda, alienados dos rastros que a produção de conhecimento sobre elas deixa. Afinal, "as ciências não falam do mundo, mas constroem representações que ora parecem empurrá-lo para longe, ora trazê-lo para perto" (Latour, 2001, p. 46).

A contribuição dos viajantes naturalistas para o conhecimento da flora brasileira é incalculável. Contudo, ainda que reconheçamos a inseparabilidade entre o exemplar coletado e o vegetal que permanece na serra, as coleções e publicações resultantes de seus estudos são ainda mantidas em arquivos estrangeiros. Muitos dos quais inexplorados e/ou contendo espécies provavelmente já extintas no momento presente. Nesse sentido, se em um curso de produção do conhecimento a referência circula movendo-se para frente e para trás (Latour, 2001), quando as sempre-vivas são transformadas em signo inscrito em uma cadeia de mediações atrelada à história e as práticas da botânica, é possível afirmar que fomos alienados destas por diferentes razões.

Na botânica, a produção de conhecimento é cumulativa, isto é, está aliada às práticas de comparação que introduzem uma relação de dependência entre pesquisadores e suas inscrições. Para cada espécie, há um único espécime - uma única inscrição - designado pelo autor da primeira descrição como o tipo nomenclatural. Esta inscrição (exsicata ou ilustração) é o documento de consulta válido para pesquisadores que venham a trabalhar com essa espécie futuramente. Logo, como no caso apresentado o signo está separado geograficamente dos pesquisadores brasileiros, quando eles não têm acesso a essa inscrição não se sabe se o que se descobriu aqui posteriormente são as mesmas ou outras espécies. Se o valor da exsicata local depende do valor instituído ao tipo que se encontra nos arquivos, não temos liberdade para produzir conhecimento ou para dar seguimento à cadeia de mediações como aconteceu ao longo de séculos -, sendo caracterizada uma forma de alienação.

De outra parte, é importante salientar como essas investigações científicas reforçaram as possibilidades de exploração dos "recursos" brasileiros pela Europa. Já que entre os séculos XVIII e XIX a América era ainda desconhecida em termos de História Natural (Lopes et al., 2011), os mesmos produziam um levantamento de informações ainda inéditas, ademais baseadas em descrições que inevitavelmente carregavam em si o olhar eurocentrado.

Como nas academias de ciências europeias do século XIX estudar os humanos também era importante para compreender a natureza, em sua passagem pelo Espinhaço Martius retratou os modos de vida nas vilas e pequenos arraiais que se formavam ao longo do caminho do ouro e dos diamantes. Ao mesmo tempo, o 
naturalista buscou conhecer os sertões mineiros. Regiões consideradas desérticas, menos por serem inabitadas e mais por serem ocupadas por indígenas e mestiços, classificados como humanos em estado primordial pelos padrões de categorização científica da época. Desta maneira, em sua obra, o sertão se vê representado ora como terra que poderia ser melhor aproveitada se manuseada adequadamente, ora como natureza intocada.

Quase parece que a natureza escolheu para a região originária dessas pedras preciosas os mais esplêndidos campos e os guarneceu com as mais lindas flores. Todo o Distrito Diamantino parece um jardim artisticamente plantado, a cuja alternativa de românticos cenários alpestres, de montes e vales, se aliam mimosas paisagens de feição idílica. (...) Na região em que cavalgávamos agora, parecia que todas essas formas se houvessem harmonizado num todo encantador. Os outeiros e vales serpeantes, interrompidos por montanhas isoladas, sio bordados, ao longo do sopé delas, e nos vales, animados por claros regatos com mata de folhagem densa de árvores sempre virentes; junto das encostas estendem-se contínuos campos verdes, interrompidos por moitas de arbustos de toda espécie, e sobre as lombadas pouco inclinadas expandem-se as mais bonitas campinas, nas quais estão distribuídas Liliáceas, moitas baixas de arbustos e arvorezinhas isoladas, enfeitadas com variegadas flores, de modo tão encantador, que se caminha por meio delas, como se fosse num parque artisticamente plantado. O próprio solo desse jardim natural é coberto de fragmentos de itacolomito de brancura deslumbrante, onde pequenas nascentes sussurram serpeantes, aqui e acolá. Finalmente, aparecem os últimos topos das lombadas muito fragmentados e fendidos, restos do tempo que renova incessantemente, como ruínas singularmente românticas, mostrando arbustos isolados e liquens. Sente-se o viajante, nesses deliciosos jardins, atraído de todos os lados por novos encantos e segue extasiado pelos volteios do caminho sempre nas alturas que o leva de uma a outra das belezas naturais. Volvendo o olhar do pacífico e variegado ambiente para a distância, o espectador vê-se todo contornado por altas montanhas rochosas que, iluminadas pelos ofuscantes raios solares, refletem uma luz resplandecente de seus vértices brancos, recortados em forma maravilhosa (Spix; Martius, [1824] 1981, p. 27, grifo nosso).

Esses relatos de importância interdisciplinar (Figura 2) vieram a contribuir com a historiografia brasileira e permitem o resgate da construção narrativa sobre uma região que, antes delimitada com base nos interesses de exploração de sua riqueza mineral (o Distrito Diamantino), atualmente é considerada um centro de diversidade vegetal pela International Union for Conservation of Nature (IUCN) devido a sua riqueza florística (Kury, 2001; Meyer; Franceschinelli, 2010). E reconhecida como Reserva da Biosfera ${ }^{10}$ (REBIO) pelo programa "O Homem e a Biosfera", da United Nations Educational, Scientific and Cultural Organization (UNESCO). Projetos que séculos depois ainda refletem sobre os trópicos uma visão de natureza apartada da vida humana.
10 As Reservas da Biosfera compõem uma rede mundial de áreas que têm por finalidade a Pesquisa Cooperativa, a Conservação do Patrimônio Natural e Cultural e a Promoção do Desenvolvimento Sustentável. Seu gerenciamento é trabalho conjunto de instituições governamentais, não governamentais e centros de pesquisa. 
Interessadas na flora de Oreades ou do Cerrado, como é conhecido atualmente, instituições governamentais, não governamentais e centros de pesquisa têm desenvolvido estudos no Espinhaço. Estes destacam a diversidade biológica da cordilheira, principal centro de ocorrência de sempre-vivas no mundo, com cerca de $70 \%$ de todas as espécies. Entretanto, visto que os campos rupestres serão uma das principais regiões atingidas pelas mudanças climáticas e considerando-se a destruição das chamadas reservas naturais no momento presente, suas pesquisas se justificam na necessidade de conhecer espécies ameaçadas de extinção e produzir técnicas para sua preservação e conservação.

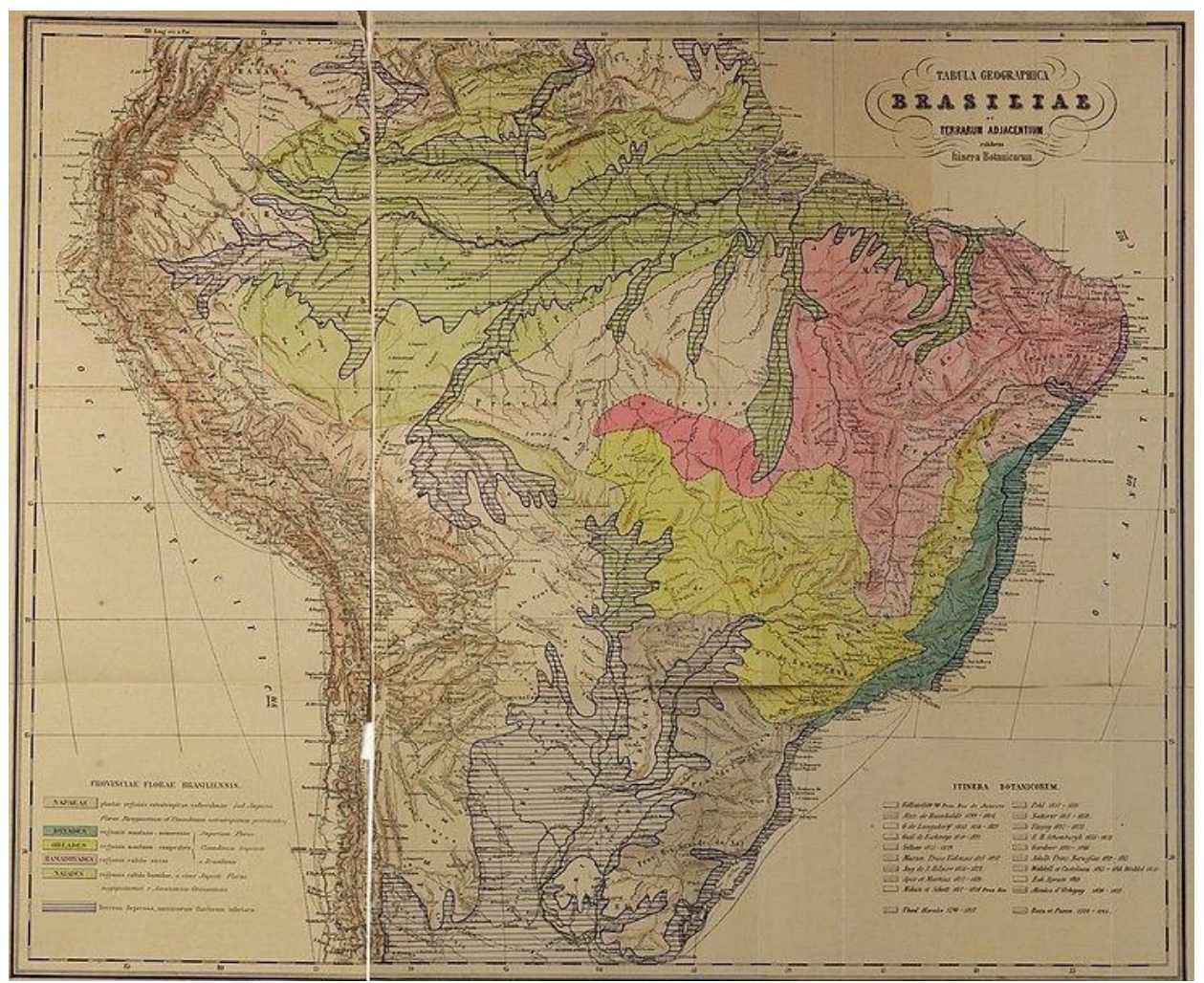

Hoje majoritariamente realizados por brasileiros, os estudos taxonômicos sobre a flora local ainda são produzidos no ir e vir entre a coleta nos campos, herborização e as análises produzidas nos laboratórios. Estas últimas, no intuito de ouvir o que as sempre-vivas têm a dizer, valem-se dos mais distintos instrumentos. Das lupas aos mais sofisticados microscópios, em anos recentes passando pelas análises genéticas. Olhos inanimados e materiais que lhes permitem observar o mundo, construir e reconstruir descrições que relacionam o nome "sempre-viva" a um grupo que abriga espécies das famílias Eriocaulaceae, Xyridaceae, Cyperaceae, Rapataceae e Compositae. Todavia, aplicado popularmente à maioria das espécies da família Eriocaulaceae.

Em geral, as sempre-vivas são caracterizadas como plantas que possuem uma roseta de folhas dispostas em espiral. Dessa roseta partem os escapos, ou hastes, que portam em seu ápice as inflorescências. As flores possuem um ou dois milímetros de comprimento, havendo de algumas dezenas a centenas delas por inflorescência (Echternacht et al., 2012). As inflorescências são capítulos às vezes
Figura 2: Prancha Geográfica do Brasil e de terras adjacentes contendo cinco Provinciae, tipos fisionômicos da paisagem florística brasileira que correspondem aproximadamente aos domínios ou biomas atuais. Destaque para a nomeação das Provinciae de acordo com ninfas da mitologia clássica: Naiades (florestas amazônicas) em verde claro; Hamadryades (caatingas) em rosa; Oreades (campos do Planalto Central) em amarelo; Dryades (florestas atlânticas) em verde escuro; Napaeae (campos meridionais) em cinza. Fonte: Martius; Eichler; Urban (Orgs.), 1906. 
esféricos, às vezes achatados e mantêm a aparência de estruturas vivas, mesmo depois de destacadas e secas (Giulietti et al., 1988).

Investigações sobre distribuição geográfica indicam que elas habitam terrenos que variam de secos a alagados. E apesar da aparente plasticidade, não sobrevivem com facilidade fora de sua área de ocorrência, fator determinante para que muitas espécies estejam seriamente ameaçadas (Costa; Trovo; Sano, 2008). Esta ameaça traz à rede sociotécnica das sempre-vivas pesquisadores interessados em desenvolver estudos sobre manejo controlado ex situ, com o desenvolvimento de protocolos de germinação in vitro para diversas espécies, bem como técnicas para sistemas de cultivo (Oliveira et al., 2014, 2015). Há ainda os que objetivam desenvolver parâmetros para a conservação das espécies in situ, tais como aqueles que tratam do uso do fogo como técnica de manejo controlado (Neves; Bedê; Martins, 2011).

Como em outras savanas, as espécies de cerrado evoluíram com o fogo, sendo as queimadas naturais responsáveis pela ciclagem de nutrientes, estímulo à reprodução, rebrota e estruturação das comunidades vegetais (Neves; Bedê; Martins, 2011; Sarmiento, 1992; Simon et al., 2009). Estudos realizados em Minas Gerais conectam o manejo do fogo a um provável incremento na germinação das sempre-vivas. Isto porque suas sementes são muito pequenas e fotoblásticas positivas, têm o comportamento germinativo favorecido por estímulos luminosos. Logo, interferindo na penetração de luz no solo, a cobertura vegetal competidora provocaria a inibição do crescimento de suas plântulas. Sendo que, quando a cobertura herbácea é eliminada, a floração dos campos se dá de maneira mais acentuada (Neves; Bedê; Martins, 2011; Nunes, 2008).

Acompanhando o zigue-zague de preocupações do qual estes pesquisadores dão conta, quando eles falam do fogo falam de si e da disposição da ciência moderna em "apropriar-se de formulações ontológicas outras as colocando em relação com as nossas” (Sá, 2015, p. 43). Derivada da técnica indígena da coivara, a queimada é tradicionalmente utilizada no Espinhaço. Tanto nas práticas agrícolas, como para renovar a pastagem natural e os campos de sempre-vivas. Desta maneira, nesse emaranhado de relações onde as sempre-vivas falam dos cientistas, os cientistas falam do apocalipse e das práticas agrícolas locais, estas plantas nos levam novamente aos humanos do lugar.

Como discutimos anteriormente, durante o Brasil colônia a região do Distrito Diamantino foi alvo de exploração mineral. Sendo suas terras devolutas refúgio para quem não possuía acesso à terra formal. Ao longo do século XX e início do século XXI, estes locais se mantiveram como espaço de gestão coletiva. Isto posto, a relação entre humanos e não-humanos que ocupam atualmente as serras da porção meridional do Espinhaço é reflexo não só dessa ancestralidade, mas de coadaptação e diversidade em movimento no espaço-tempo.

Nas distintas comunidades rurais dos arredores de Diamantina vivem homens e mulheres que se auto reconhecem apanhadores(as) de flores sempre-vivas, e que ao se relacionarem com estas flores compõem uma rede na qual se associam a todos os atores humanos e não-humanos dos quais tratamos até aqui, bem como aos que descreveremos adiante. 
Próximos às suas casas estão os animais domesticados. Equinos, muares e bovinos são aliados como meio de tração, transporte de carga e pessoas, e alguma produção de leite. Os cães e gatos fazem companhia. Galináceos e suínos são os responsáveis pela conversão dos restos de matéria orgânica em proteína.

Nos quintais e nas roças desenvolve-se a agricultura, o chão onde resiste grande parte dos saberes locais nos plantios de subsistência. Nos quintais estão as hortas e pomares, onde se encontra uma infinidade de plantas alimentícias, condimentares e medicinais. Tais como couve, mamão, chicória, alface, chuchu, taioba, limão, mostarda, jiló, tomate, mamão, melancia, maxixe, laranja, mexerica, abóbora, urucum, boldo, erva-cidreira, alecrim, capim santo, erva doce, etc.

As roças são áreas maiores, onde se trabalha principalmente no período chuvoso que vai de novembro a março. Cultivadas de acordo com as fases da lua, elas podem estar nas áreas mais baixas ou sobre a serra, em terras mais úmidas ou mais secas, e se movimentam com as técnicas de rotação de culturas e pousio respectivamente a alternância de espécies vegetais numa mesma área agrícola e repouso das terras cultiváveis após o plantio por três anos sucessivos.

Caminhar por estas roças é misturar-se com uma infinidade de vegetais em distintas variedades e quase sempre semeados em associação. Arroz, milho, quiabo, feijão, mandioca, cana, batata doce, inhame, banana, alho, etc., são algumas das centenas de plantas com as quais os agricultores do Espinhaço ao longo de incontáveis gerações têm se relacionado. E produzido ciência e técnicas de armazenamento e seleção de sementes, hibridização de espécies em cultivos consorciados, beneficiamento da produção agrícola, etc.

Entre abril e outubro chega a estiagem, ou o tempo da seca, quando o trabalho na roça diminui e o gado é transportado para as pastagens dos campos nativos, onde simultaneamente é feita a maior parte da "panha" ${ }^{11}$ de flores (Imagem 1). Neste período, famílias de diferentes comunidades se encontram no alto das serras. Transitando por esse multiverso, os(as) apanhadores(as) estabeleceram relações com tudo que "dá na chapada".
11 Derivado do verbo apanhar, que designa o ato de recolher com auxílio das mãos ou de objeto, tomar, amparar ou segurar com a(s) mão(s). Termo utilizado pelos(as) apanhadores(as) do Espinhaço para denominar a coleta de espécies nativas ou não.

Imagem 1: Prancha fotográfica, apanhadores(as) de sempre-vivas do Espinhaço Meridional-MG. Da esquerda para a direita: organização dos buquês após a panha, transporte do material coletado e momento da panha. Fonte: Fotos de André Dib e João Roberto Ripper.

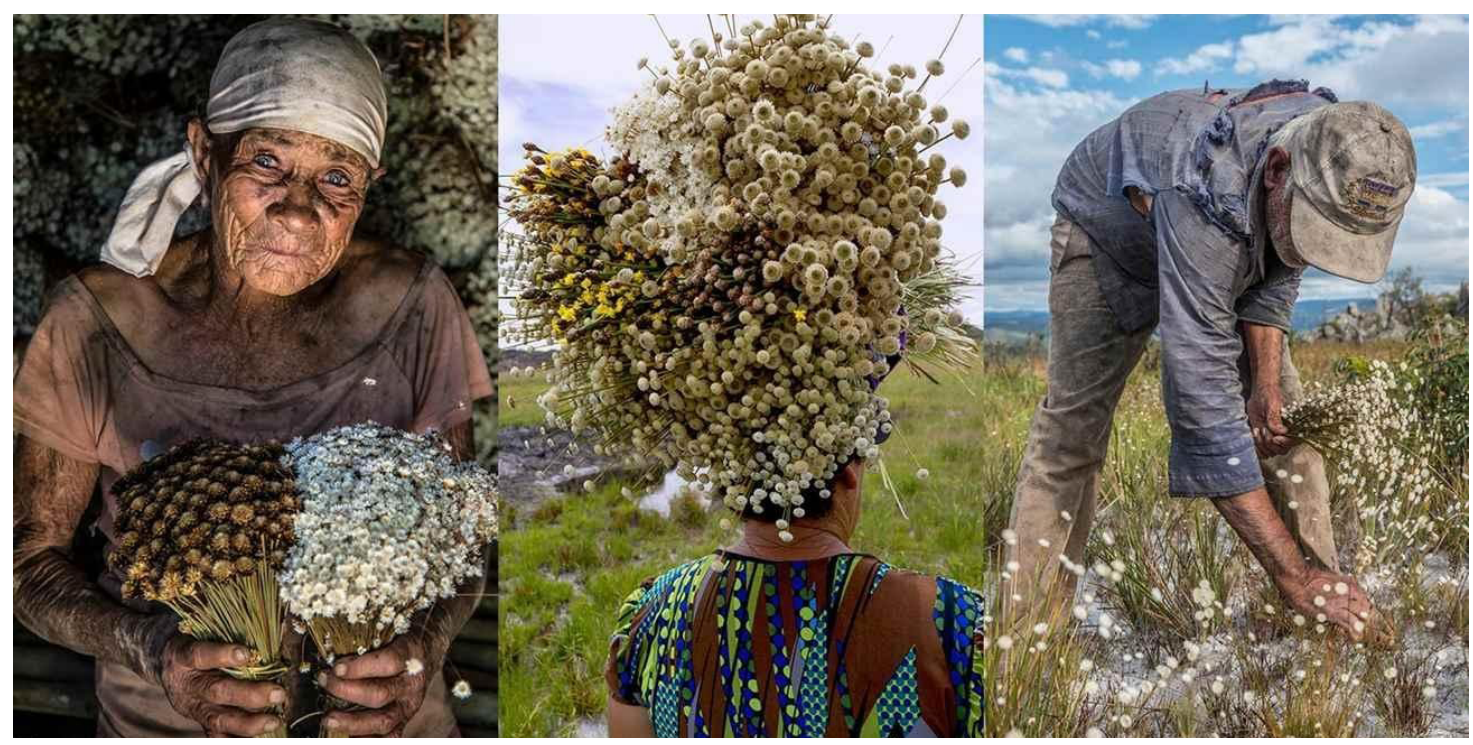


Nesse cosmos de relações entre humanos, plantas e outros-que-não-humanos, as ciências produzidas pelos(as) apanhadores(as) e suas flores também está permeada por técnicas.

Para as plantas, como seres sésseis, o encontro com o outro é possível através da metamorfose de si. As flores são os apêndices, atratores cósmicos, ou espaço da mistura. Este agregado de diferentes órgãos modificados - onde o organismo e a espécie são decompostos e recompostos - contém o conjunto dos procedimentos técnicos e materiais necessários para produzir outros indivíduos. Elas são, portanto, a coincidência absoluta entre vida e técnica, matéria e imaginação (Coccia, 2018).

Ainda, visto que, para além das trocas de energia, os organismos estão situados em emaranhadas histórias, estas flores evidenciam como formas particulares de vida "em toda a sua diversidade resplandecente, emergem de padrões entrelaçados de viver e morrer, de ser e tornar-se, em um mundo maior" (Van Dooren; Kirksey; Münste, 2016, p. 41).

A íntima relação entre uma flor e sua abelha polinizadora é aquela em que ambas as formas de vida são modeladas e se tornam possíveis através de um patrimônio comum, um entrelaçamento que Isabelle Stengers caracteriza como "captura recíproca". Como tal, elas não simplesmente se encontram - esta abelha e esta flor -, mas, ao invés disso, a sua relação emerge a partir de histórias co-evolutivas, a partir de ricos processos de co-tornar-se (Van Dooren; Kirksey; Münste, 2016, p. 41).

Nesse sentido, as sempre-vivas como lugar de indiferença entre o biológico e o cultural são flores que também carregam em si a impossibilidade de purificação da presença humana. De modo que em seus nomes, no modo como são descritas, panhadas, semeadas etc., está singularizada esta transformação mútua.

O termo "flores" faz referência às inflorescências esbranquiçadas, com formato de "margaridinha". Aquelas com outras formas e cores são chamadas de "botões”. Dentre as flores, as mais citadas são as de janeiro, pé de ouro, carrasqueira, sapatinha e chapadeira. Considerando os botões, o branco de janeiro ou capoeira, o branco de novembro ou capoeira bordado, a jazida amarela, a sedinha ou capim-dourado, o espeta-nariz, o cebolão, o amarelinho, o mundial e o cabeça de nego, etc. Nomes que singularizam associações entre a história da exploração do ouro, os homens e mulheres que ali viveram e vivem, a morfologia, o tempo (ciclo de vida) e a distribuição geográfica dos vegetais. A esse respeito é interessante destacar como de acordo com o mês do ano apanhadores e apanhadoras sabem qual variedade está florescendo e em que lugar da serra. Já que há as espécies que nascem nas grotas, próximo a pedras ou áreas mais úmidas, como também as que se reproduzem em ambientes com solo mais seco e arenoso.

A panha, assim como a lida na roça, é uma atividade coletiva que reúne os mais velhos, adultos e crianças. Em geral é feita no período da manhã, quando as hastes ainda molhadas de orvalho se desprendem com maior facilidade do pé, e 
as flores já secas pelos primeiros raios de sol estão abertas.

É preciso ser hábil para que ao manusear as flores e botões, não se arranquem do solo as plantas inteiras, já que elas podem florescer novamente - em menor quantidade no mesmo ano e na mesma proporção no ano seguinte. Ainda uma porcentagem de flores não panhadas - o restolho - é responsável pela manutenção populacional.

À medida que são coletadas com uma das mãos, as sempre-vivas vão sendo armazenadas na outra, formando um pequeno buquê. Este simultaneamente ajeitado com as pontas dos dedos e pela remoção de algumas flores colhidas ainda fechadas ou com hastes quebradas. Os buquês, que aos poucos vão se aglomerando no solo, ao fim são recolhidos e amarrados em grandes feixes nos lombos de cavalos e burros, e assim transportados aos ranchos - construídos de madeira ou adobe e cobertos com folhas de espécies locais - e às lapas - abrigos rochosos dos quais falamos anteriormente. Ali vestígios arqueológicos pré-históricos convivem com vestígios de ocupações contemporâneas: fogões feitos de blocos de quartzito, colchões de capim nativo, jiraus, além de caules de gramíneas, e outros resíduos da coleta das flores (Horta, 2009). Tais como as sementes, que são recolhidas e devolvidas aos campos ${ }^{12}$.

No período que estão no alto da serra, a dieta de apanhadores(as) conta com parte do alimento trazido de suas casas e é complementada com alimentos nativos. Araçá, mangaba, caju do campo, panã, pequi, jaboticaba do mato, gabiroba, coco do mato, etc., de cada um destes eles conhecem onde, como e quando o pé frutifica. Saberes resistentes passados adiante na experiência do contato com o lugar, reconstruídos no presente e inundados de passado, trazem o modo de vida do garimpeiro, do indígena, do preto que se embrenhou no mato e dele retirava seu sustento.

No co-tornar-se entre esses homens e mulheres, suas hortas, roças, campos e flores, mesmo não sendo a panha a única atividade que eles realizam, são as sempre-vivas o elo que os aglutina e torna evidente como os(as) apanhadores(as) aprenderam com a serra a privilegiarem a diversidade. Deste modo, na experiência da pluriatividade produziram e produzem conhecimentos e técnicas que foram e continuam sendo fundamentais para a sobrevivência humana em condições muitas vezes adversas. O que demonstra que a relação entre apanhadores(as) e sempre-vivas não se trata apenas de uma atividade extrativista, mas de um cosmos. Contudo, são as associações econômicas que eles estabelecem com as plantas do lugar $^{13}$ o que toma centralidade no senso comum e que permeia a produção de políticas públicas ambientais para o Espinhaço.

Após a panha das sempre-vivas, as flores reunidas em buquês são secas ao sol e vendidas in natura a intermediários - que fazem a ligação com revendedores e exportadores $^{14}$ - ou tingidas e utilizadas para produção de peças artesanais comercializadas localmente (Imagem 2).
12 Tecendo nosso relato no caminho entre a dúvida absoluta e as verdades indiscutíveis, ao descrever as dinâmicas que permeiam associações neste coletivo heterogêneo nos indagamos: até que ponto a associação entre populações humanas locais e essas plantas determina as áreas de ocorrência das mesmas no momento presente?

13 Vista a dinâmica entre apanhadores(as), plantas, flores e sementes de sempre-vivas, como podemos demarcar onde começa e onde termina o panhar e o plantar? Se a hibridização entre apanhador(a) e sempre-viva borra as fronteiras entre humanos e flor, extrativismo e a agricultura, o mesmo se dá entre agricultura, produção artesanal e comércio.

14 O mercado de flores sempre-vivas gera renda para a população local desde o início do século XX. A primeira exportação registrada foi para Viena, na Áustria, e ocorreu na década de 1930. O comércio decolou durante a Segunda Guerra Mundial, quando as flores secas eram colocadas nos caixões de soldados. Seu auge ocorreu entre os anos 1970 e 1980, como reflexo de uma demanda internacional pelo produto. Neste período, os maiores importadores eram Estados Unidos da América, Itália, Japão e Alemanha (Giulietti et al., 1988). 


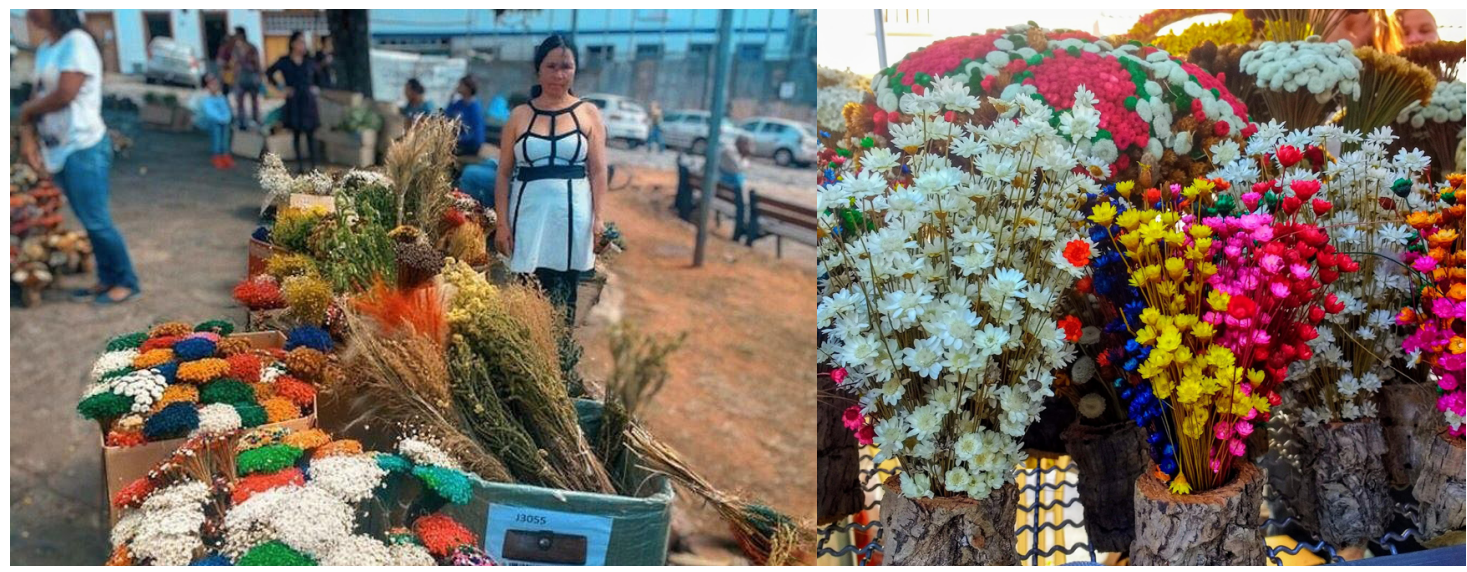

Imagem 2: Prancha fotográfica, comércio de flores sempre-vivas no Mercado Velho em Diamantina-MG. Apanhadora vendendo flores à esquerda e artesanato à direita. Fonte: Foto da autora, 2019.

Como o extrativismo de flores com fins comerciais foi em décadas passadas considerado um dos fatores responsáveis pela sobrecoleta, queima indiscriminada de vegetação nativa e declínio das populações de sempre-vivas do Espinhaço (Giulietti et al., 1988), nos últimos anos diversas comunidades rurais locais tiveram o acesso aos campos de coleta suspenso ou restrito. Sobretudo dentro dos limites de unidades de conservação (UCs) criadas na região ${ }^{15}$, onde as queimadas e a coleta de espécies nativas são vistas como uma ameaça a ser combatida intensivamente, ainda que, como vimos anteriormente, estudos experimentais apontem as controvérsias inerentes ao uso do fogo. E que os(as) apanhadores (as) apontem a expansão dos monocultivos da agroindústria sobre a serra como um dos principais fatores de degradação.

Dentre tais UCs, destacamos o Parque Nacional das Sempre-Vivas, unidade de proteção integral gerida pelo Instituto Chico Mendes de Conservação da Biodiversidade (ICMBio). Criado por decreto presidencial em 2002 sem a devida consulta às comunidades locais e demarcado em um sobrevoo, o mesmo compreende áreas dos municípios de Olhos d’Água, Bocaiúva, Buenópolis e Diamantina. Sobrepondo-se a inúmeras comunidades rurais. Desde então, muitas famílias começaram a relatar terem sido ameaçadas, multadas e lesadas com a destruição de seus ranchos no interior do parque.

Como foi possível perceber em distintas falas de moradores das comunidades de Mata dos Criolos, Raíz, Galheiros e etc., após denúncias e abertura de processos perante o Ministério Público, quase duas décadas após a criação do parque a questão segue em aberto. Persiste na região um projeto de conservação da natureza baseado tanto nos planos de manejo de UCs como na matriz de planejamento do Plano de Ação Nacional para Conservação das Eriocaulaceae no Brasil (PAN Sempre-Vivas) ${ }^{16}$, sendo que em ambos é notável a quase ausência de propostas que incluam os povos do Espinhaço.

Tais fatos poderiam nos impelir à redução da controvérsia ecológica relativa à superproteção ou superexploração dessas plantas a um conflito dual entre conservacionistas e apanhadores (as). Contudo, constatar o conflito em si não nos interessa, já que ambos têm a mesma preocupação: as sempre-vivas. Sendo assim,
15 Como o Espinhaço já havia sido identificado como umas das áreas de alta prioridade para manejo e criação de Unidades de Conservação no âmbito do Programa Nacional de Biodiversidade, a criação de UCs na região cumpre com diretrizes governamentais para ampliação da proteção do Cerrado brasileiro (Brasil, MMA/ ICMBIO, 2016, p. 21).

16 Considerando os compromissos assumidos pelo Brasil na Convenção sobre Diversidade Biológica (CDB), são três os instrumentos de implantação da Política Nacional da Biodiversidade voltados para a conservação e recuperação de espécies ameaçadas de extinção. Listas reconhecem as espécies na condição de ameaçadas, os Livros VermeIhos detalham as informações que embasaram a inclusão das espécies nas Listas, e os Planos de Ação estabelecem as medidas a serem implantadas para a conservação e recuperação das espécies ameaçadas. 0 Plano de Ação Nacional para a Conservação das Eriocaulaceae do Brasil - PAN Sempre Vivas inclui 20 espécies relacionadas na Lista Oficial da Flora Brasileira Ameaçada de Extinção. 
em uma época onde se parece viver entre o apocalipse ambiental e a salvação através das técnicas, deixamo-nos afetar pelas plantas. E, optando por considerar a anarquia do rizoma em detrimento da árvore do conhecimento (Deleuze; Guattari, 1995; Stengers, 2017), temos nos indagado sobre as possibilidades de imaginarmos um mundo comum.

\section{Considerações finais: sobre a necessidade de se pensar com as plantas}

Na biologia, o rizoma é um caule mais ou menos cilíndrico, como bulbos e tubérculos, que cresce horizontalmente próximo à superfície do solo e apresenta todas as características de um sistema caulinar comum, mas ramificando-se lateral e circularmente de forma múltipla, diferente das raízes que tendem a crescer por meio de divisões binárias. Este modelo inspirou a teoria de Deleuze e Guattari (1995) sobre um sistema epistemológico a-centrado onde não há princípios primeiros, linhas de subordinação hierárquica de onde a estrutura do conhecimento deriva. Distinto do modelo arbóreo de organização do conhecimento com ligações localizáveis entre pontos e posições, o "rizoma não começa nem conclui, ele se encontra sempre no meio, entre as coisas, inter-ser, intermezzo. A árvore é filiação, mas o rizoma é aliança, unicamente aliança” (Deleuze; Guattari, 1995, p. 37).

Se o modo como produzimos conhecimento sobre a realidade está diretamente vinculado ao modo como fazemos política, quando a árvore e a raiz dominam o pensamento ocidental, estamos compondo este relato sobre a rede sociotécnica das sempre-vivas atentas ao pensar rizomático que a savana brasileira tem a nos ensinar. Pois, como é na relação com os objetos, coisas, seres diversos que nos avivamos (Stengers, 2017), admitir que não estamos sozinhos no mundo passa tanto por descolonizar nossas relações com os não-humanos, como também pela descolonização de nossas relações com outros humanos e suas ontologias.

Temos ainda um longo caminho a percorrer no labirinto onde as sempre-vivas falam das humanidades, e os humanos falam de si quando falam dos vegetais. Entretanto, ao ver e ouvir esses atores múltiplos - indissociáveis, em uma grande mistura, tal como nos propõem estas flores em si - com a vinculação da noção de cosmopolítica à diplomacia, seguiremos trabalhando no exercício de ampliar nossa capacidade de produzir acordos sem anular desentendimentos (Stengers, 2018). Mais uma vez, e definitivamente, se existem tantas maneiras de cultivar a diferença, o que nos move é a necessidade de panhar e compor um mundo onde caibam muitos mundos (De La Cadena, 2018).

Se o Antropoceno está marcado pelas lógicas extrativistas do capitalismo e pelo poder destrutivo do colonialismo, nosso interesse é documentar ecologias afetivas que se formam entre plantas e pessoas, renovando o que a ecologia e o que a política têm nos ensinado. Afinal, na tecitura de nosso cosmograma foi possível entender como as sempre-vivas - em particular - tal como as plantas - em geral - estão em muitas partes/coisas, compondo objetos, modos de vida e trabalho, legislação ambiental, artigos científicos e a narrativa da opinião pública. Estão em muito do que sabemos sobre agricultura; estão na origem do mundo como o conhecemos, na origem do ato de respirar. 
Desta maneira, visto que etnografar seguindo o princípio da simetria pressupõe explicar com os mesmos termos verdades e erros, estudar ao mesmo tempo a produção de humanos e não-humanos, e ocupar uma posição intermediária entre os terrenos tradicionais e os novos (Latour, 1994, p. 101-102), as sempre-vivas sugerem a possibilidade de composição de um mundo não apenas menos antropocêntrico. Elas indicam a possibilidade de composição de um mundo menos hierárquico entre os próprios humanos e os conhecimentos produzidos em seus coletivos.

Essas plantas - sua história, evolução e sua capacidade de fundar novos mundos sem violência - nos convidam a pensar o mundo como conjunto do que foi, é e será. Sua cosmogonia, flores e sementes que guardam como a planta deve ser e a planta propriamente dita - conceito e contexto, sem descontinuidade e distinção - impõe à biologia, ecologia, antropologia, filosofia, e etc., repensar as relações entre mundo e ser vivo, epistemologia e política. Da mesma maneira, sua vida híbrida, enraizada ao multiverso do Espinhaço e devota ao céu, nos demonstra ser necessário discutir a renúncia consciente e voluntária ao saber dos outros. Pois, se as coisas, seres e ideias misturam-se, nos cabe concluir que neste mundo onde nada está ontologicamente separado do resto, é inevitável que o conhecimento transforme

em ideia qualquer matéria, objeto ou acontecimento, exatamente como as plantas são capazes de transformar em vida qualquer pedaço de terra, de ar e de luz. Essa seria a forma mais radical da atividade especulativa, uma cosmologia proteiforme e liminar, indiferente aos lugares, às formas, às maneiras como é praticada (Coccia, 2018, p. 115). 


\section{Referências}

AMADO, Janaína. Região, sertão, nação. Estudos Históricos, n. 8, p. 145-151, 1995.

BRASIL. Ministério do Meio Ambiente. Instituto Chico Mendes de Proteção da Biodiversidade (ICMBio). Plano de manejo do Parque Nacional das Sempre-Vivas. Brasília: ICMBio, 2016.

CALVO, Paco. What is it like to be a plant? Journal of Consciousness Studies, n. 24, p. 205227, 2017.

CHEMALE JR, Farid; DUSSIN, Ivo Antônio; MARTINS, Maximiliano; SANTOS, Marcelo. Nova abordagem tectono-estratigráfica do Super grupo Espinhaço em sua porção meridional (MG). Geonomos, n. 19, p. 173-41.2011.

COCCIA, Emanuele. A vida das plantas: uma metafísica da mistura. Florianópolis: Cultura e Barbárie, 2018.

COSTA, Fabiane Nepomuceno; TROVÓ, Marcelo; SANO, Paulo Takeo. Eriocaulaceae na Cadeia do Espinhaço: riqueza, endemismo e ameaças. Megadiversidade, n. 4, p. 7785, 2008.

CRUTZEN, Paul J.; STOERMER, Eugene F. The Anthropocene. Global Change Newsletter, n. 41, p. 12-13, 2000.

DE LA CADENA, Marisol; BLASER, Mario (Eds.). A world of many worlds. Durham: Duke University Press, 2018.

DE OLIVEIRA, Roberto Cardoso. O trabalho do antropólogo: olhar, ouvir, escrever. Revista de Antropologia, n. 39, p. 13-37, 1996.

DELEUZE, Gilles; GUATTARI, Félix. Mil Platôs - Capitalismo e Esquizofrenia. v. 1. Rio de Janeiro: Editora 34, 1995.

ECHTERNACHT, Livia; TROVÓ, Marcelo; COSTA, Fabiane Nepomuceno; SANO, Paulo Takeo. Análise comparativa da riqueza de Eriocaulaceae nos parques estaduais de Minas Gerais, Brasil. MGBiota, n. 4, p. 18-31, 2012.

ESCHWEGE, Wilhelm Ludwig. Quadro Geognóstico do Brasil e a provável rocha matriz dos diamantes. Trad. de F. E. RENGER do original em alemão (1822). Geonomos, n. 13, p. 97-109, 2005.

GIULIETTI, Nelson; GIULIETTI, Ana Maria; PIRANI, José Rubens; MENEZES, Nanuza Luiza. Estudos em sempre-vivas: importância econômica do extrativismo em Minas Gerais, Brasil. Acta Botânica Brasílica, n. 1, p. 179-193, 1988.

HALPIN, Claire; MCKIM, Sarah. "Plant blindness" is obscuring the extinction crisis for non-animal species. The Conversation. 2019. Disponível em: http://theconversation.com/plant-blindness-is-obscuring-the-extinction-crisis-for-non-animal-species-118208. Acesso em: 19 set. 2019.

HARAWAY, Donna. Antropoceno, Capitaloceno, Plantationoceno, Chthuluceno: fazendo parentes. ClimaCom Cultura Científica - pesquisa, jornalismo e arte, n. 5, p. 139-146, 2016.

HORTA, Andrei Isnardis. Entre as pedras: as ocupações pré-históricas recentes e os grafismos rupestres de Diamantina, Minas Gerais. Tese (Doutorado em Arqueologia) - Universidade de São Paulo, São Paulo, 2009.

IBGE - INSTITUTO BRASILEIRO DE GEOGRAFIA E ESTATÍ́STICA. Mapa de unidades de relevo do Brasil. Escala 1: 5.000.000. IBGE, 2006.

KURY, Lorelay. Viajantes-naturalistas no Brasil oitocentista: experiência, relato e ima- 
gem. História, Ciências, Saúde - Manguinhos, n. 8, p. 863-880, 2001.

LATOUR, Bruno. A Esperança de Pandora: ensaios sobre a realidade dos estudos científicos. Bauru: EDUSC, 2001.

LATOUR, Bruno. Cogitamus: seis cartas sobre as humanidades científicas. São Paulo: Editora 34, 2016.

LATOUR, Bruno. Jamais fomos modernos: ensaio de antropologia simétrica. Tradução de Carlos Irineu da Costa. Rio de Janeiro: Editora 34, 1994.

LATOUR, Bruno. Reagregando o social: uma introdução à Teoria Ator-Rede. Salvador: EdUFBA; Bauru: EDUSC, 2012.

LOPES, Fabrício Antônio; MILAGRES, Alcione Rodrigues; PIUZANA, Danielle; DE MORAIS, Marcelino Santos. Viajantes e Naturalistas do século XIX: a reconstrução do antigo Distrito Diamantino na Literatura de Viagem. Caderno de Geografia, n. 21, p. 66-86, 2011.

MACKENZIE, Caitlin McDonough; KUEBBING, Sara; BARAK, Rebecca S; BLETZ, Molly; DUDNEY, Joan; MCGILL, Bonnie M; NOCCO, Mallika; YOUNG, Talia; TONIETTO, Rebecca K. We do not want to "cure plant blindness" we want to grow plant love. Plants, People, Planet, n. 1, p. 139-141, 2019.

MARRAS, Stelio. Por uma antropologia do entre: reflexões sobre um novo e urgente descentramento do humano. Revista do Instituto de Estudos Brasileiros, n. 69, p. 250266, 2018.

MARTIUS, Carl Friedrich Philipp von; EICHLER, August Wilhelm; URBAN, Ignatz (Orgs.). Flora Brasiliensis (15 vol.). Leipzig, 1906, digitalizado. Disponível em: http://florabrasiliensis.cria.org.br/. Acesso em: 28 nov. 2019.

MEYER, Sylvia Therese; FRANCESCHINELLI, Edivani Villaron. Estudo florístico de plantas vasculares associadas às áreas úmidas na Cadeia do Espinhaço (MG), Brasil. Revista Brasileira de Botânica, n. 33, p. 667-691, 2010.

MOORE, Jason W. Anthropocene or Capitalocene? Nature, History, and the Crisis of Capitalism. In: ALTVATER, Elmar; CRIST, Eileen; HARAWAY, Donna Jeanne; HARTLEY, Daniel; PARENTI, Christian; MCBRIEN, Justin; MOORE, Jason. Anthropocene or capitalocene?: Nature, history, and the crisis of capitalism. Oakland: PM Press, 2016.

MYERS, Natasha. A kriya for cultivating your inner plant. Centre for Imaginary Ethnography, Imaginings Series, p. 1-6, 2014.

NEVES, Ana Carolina de Oliveira; BEDÊ, Lúcio Cadaval; MARTINS, Rogério Parentoni. Revisão sobre os Efeitos do Fogo em Eriocaulaceae como Subsídio para a sua Conservação. Biodiversidade Brasileira, n. 2, p. 50-66, 2011.

NICHOLS, Mary H; STEVEN; Janet C; SARGENT, Randy; DILLE, Paul; SCHAPIRO, Joshua. Very-high-resolution time-lapse photography for plant and ecosystems research. Applications in Plant Science, n. 1, p. 1-6, 2013.

NUNES, Silvia Cristina Paslauski. Respostas fisiológicas, fenológicas e anatômicas de Syngonanthus elegans (Bong.) Ruhland e Syngonanthus elegantulus Ruhland cultivadas sob dois níveis de radiação em Diamantina, MG. Dissertação (Programa de Pós-Graduação em Produção Vegetal) - Universidade Federal dos Vales do Jequitinhonha e Mucuri, Diamantina, 2008.

OLIVEIRA, Maria Neudes Sousa; CRUZ, Sarah Michelly; SOUSA, Amanda Miranda; MOREIRA, Fernanda da Conceição; TANAKA, Mário Kiichiro. Implications of the harvest time on Syngonanthus nitens (Bong.) Ruhland (Eriocaulaceae) management in the 
state of Minas Gerais. Brazilian Journal of Botany, n. 37, p. 95-103, 2014.

OLIVEIRA, Maria Neudes Sousa; DIAS, Bruna Anair Souto; ANDRADE, Guilherme Carvalho; TANAKA, Mário Kiichiro; ÁVILA, Rafael Gualberto; SILVA, Luzimar Campos. Harvest times of Comanthera elegans, a worldwide traded Brazilian species of everlasting flower: implications on seed production, germination, and on species management. Brazilian Journal of Botany, n. 38, p. 795-808, 2015.

PEREIRA, Márcio Mota. Notas sobre um sítio arqueológico deslocado: as pinturas rupestres São-Franciscanas de Andrelândia, sul de Minas Gerais. TARAIRIÚ - Revista Eletrônica do Laboratório de Arqueologia e Paleontologia da UEPB, n. 1, p. 26-39, 2013.

PROUS, André. O Brasil antes dos brasileiros: a pré-história de nosso país. 2. ed. Rio de Janeiro: Jorge Zahar, 2006.

SÁ, Guilherme José da Silva. Antropologia e não modernidade: até que a ciência as separe. ILHA Revista de Antropologia, UFSC, n. 17, p. 31-47, 2015.

SANDERS, Dawn L. Standing in the shadows of plants. Plants, people, planet, n. 1, p. 130-138, 2019.

SANTOS, Bethânia G. Resistência criativa de setores subalternos: integração e marginalização em interações socioambientais e políticas na Comunidade de Milho Verde, MG. Dissertação (Mestrado em Ciências Sociais em Desenvolvimento, Agricultura e Sociedade) - Universidade Federal Rural do Rio de Janeiro, Rio de Janeiro, 2016.

SARMIENTO, Guillermo. Adaptative strategies of perennial grasses in South America savannas. Journal of Vegetation Science, n. 3, p. 325-336, 1992.

SCHUSSLER, Elisabeth E; OLZAK, Lynn A. It's not easy being green: Student recall of plant and animal images. Journal of Biological Education, n. 42, p. 112-119, 2008.

SIMON, Marcelo F; GRETHER, Rosaura; QUEIROZ, Luciano P; SKEMA, Cynthia; PENNINGTON, R Toby; HUGHES, Colin E. Recent assembly of the Cerrado, a Neotropical plant diversity hotspot, by in situ evolution of adaptations to fire. Proceedings of the National Academy of Science, n. 106, p. 20359-20364, 2009.

SOLARI, Ana; ISNARDIS, Andrei; LINKE, Vanessa. Entres cascas e couros: os sepultamentos secundários da Lapa do Caboclo (Diamantina, Minas Gerais). Revista Habitus, n. 10, p. 115-134, 2012.

SOUZA, Juliana Marques de. Paleobotânica: o que os fósseis vegetais revelam? Ciência e Cultura, n. 67, p. 27-29, 2015.

SPIX, Johann Baptist Von; MARTIUS, Carl Friedrich Philipp von. Viagem pelo Brasil, 1817 - 1820. Trad. de Lúcia Furquim Lahmeyer. Belo Horizonte: Itatiaia; São Paulo: Edusp, 1981.

STENGERS, Isabelle. Au temps des catastrophes: Résister à la barbarie qui vient. Paris: Éditions La Découverte, 2009.

STENGERS, Isabelle. La propuesta cosmopolítica. Revista Pléyade, n. 14, p. 17-41, 2014.

STENGERS, Isabelle. Reativar o Animismo. Caderno de Leitura, n. 62. Belo Horizonte: Chão de Feira, Fundação Municipal de Cultura, 2017.

STENGERS, Isabelle. The challenge of ontological politics. In: DE LA CADENA, M.; BLASER, M. (ed.). A world of many worlds. Durham: Duke University Press, 2018.

TSING, Anna. Unruly edges: mushrooms as companion species. Environmental Humanities, n. 1, p. 141-154, 2012.

VAN DOOREN, Thom; KIRKSEY, Eben; MÜNSTE, Ursula. Estudos multiespécies: cul- 
Bethânia Gabrielle dos Santos e Fátima Teresa Braga Branquinho

tivando artes de atentividade. Trad. de Susana Dias. ClimaCom Cultura Científica (on-line), Campinas, Incertezas, n. 7, p. 39-66, 2016.. Disponível em: http://climacom. mudancasclimaticas.net.br/wp-content/uploads/2014/12/07-Incertezas-nov-2016. pdf. Acesso em: 28 nov. 2019.

WANDERSEE, James H.; SCHUSSLER, Elisabeth E. Preventing plant blindness. The American Biology Teacher, n. 61, p. 84-86, 1999. 